\title{
ТАНОК ЯК ЗАСІБ САМОВДОСКОНАЛЕННЯ ОСОБИСТОСТІ
}

\author{
Косиченко В. А. \\ старший викладач кафедри хореографії, \\ Харківський національний педагогічний університет \\ імені Г. С. Сковороди, м. Харків, Україна
}

У статті розкрито вплив таницю, зокрема ії імпровізаційної складової, на вдосконалення сутнісних сил особистості. Хореографія сприяє розвиткові ї̈ творчих якостей $і$ здібностей, зростанню внутрішніх потенціалів, пізнавальної активності й емоційної чутливості, естетичних потреб і смаків, стимулюванню прагнення до самовдосконалення.

Ключові слова: танець, імпровізація, розвиток особистості, самовдосконалення.

The article reveals the influence of dance, in particular its improvisational component, on the improvement of the essential forces of personality. Choreography promotes the development of her creative qualities and abilities, the growth of internal potentials, cognitive activity and emotional sensitivity, aesthetic needs and tastes, stimulating the desire for selfimprovement

Keywords: personal development, dance, improvisation, selfimprovement.

В даний час в умовах інтенсивних і глобальних змін, людство шукає шляхи виходу з кризових та конфліктних ситуацій. На перший план виступають питання швидкої і гнучкої адаптації особистості до швидко мінливих умов, що характеризується рівнем саморозвитку особистості. Головним завданням, яке постає зараз перед суспільством $€$ розвиток особистості, здатної до визначення особистісних засобів самореалізації, саморозвитку, самоосвіти й самоствердження, тобто самовдосконалення, як в професійній кар'єрі так і в життєдіяльності.

На різних етапах свого розвитку людство постійно зверталося до танцю як до універсального засобу виховання тіла і душі людини засобу гармонізації виховання особистості. Специфіка хореографічного мистецтва визначається його багатогранним впливом на людину, що зумовлено самою природою танцю як синтетичного виду мистецтва. Хореографія, впливаючи на емоційний розвиток особистості, допо- 
Розділ І. Ціннісні орієнтири духовно-інтелектуального виховання, розвиток духовно-інтелектуальних якостей особистості в умовах співпраці й інклюзії

магає людині удосконалити тіло фізично, набути впевненості у власних силах, духовно розвиватись, дає поштовх до постійного розвитку та самовдосконалення [5].

Феномен самовдосконалення особистості в психології переважно визначається як якість, що розширює можливості свідомості, вивільняє місце для духовного зростання, розкриття людиною своєї суті, самоактуалізації (Р. Бернс, І. Бех, М. Боришевський, М. Боуен, Г. Ковальов, І. Кон, Г. Костюк, А. Маслоу, Ю. Орлов, К. Роджерс, Л. Рувинський, та ін.).

Ідеї саморозвитку особистості, іiі здатності до самовизначення, до самовдосконалення розглянуто в працях М. Бахтіна, В. Біблера, М. Бердяєва, I. Донцова, I. Канта, С. Рубінштейна, Г. Тульчинського та ін.

Особливості впливу танцю на розвиток особистості визначали В. Борсук, Л. Гусаченко, Л. Магдисюк, Т. Царик, О. Отич та ін.

Самовдосконалення розглядається як можливість особистісного росту людини і її самостійне прагнення наблизитися до певного ідеалу 3 метою набуття рис і якостей особистості, оволодіння тими видами діяльності, якими вона поки що не володіє. Тому самовдосконалення має особливу роль у становленні особистості оскільки впливає на здатність людини пізнання власного «Я», а відповідно до рефлексії над собою. Усвідомлюючи свої досягнення і недоліки, особистість виявляє прагнення до самовдосконалення, до самоосвіти і самовиховання. Створюючи нові цінності, вона сама особистісно зростає, стає суб'єктом власного розвитку[2].

Специфіка самовдосконалення особистості полягає в тому, що воно найбільшою мірою спирається на індивідуальні особливості людини, iii нахили та потреби. Завдяки цьому людині вдається виявити для самої себе домінуючі задатки, які у майбутньому можуть суттєво визначити весь їі життєвий шлях, забезпечити розвиток фізичних, інтелектуальних і моральних якостей.

Інтенсивність і глибина змін, які відбуваються у суспільстві впливають на емоційну сферу кожної людини. У зв'язку з цим цікавим і актуальним $є$ питання саморозвитку та самовдосконалення особистості через танець, адже саме танець $є$ інтегратором всіх аспектів людини.

Характерною особливістю сучасного танцю $є$ знайомство зі станом людини «тут і зараз», яке підтримується вже у залученні учасників в цей 
процес. Це стан пов'язаний з інтеграцією інтелектуального, емоційного і фізичного аспектів, його також можна назвати станом цілісності. Саме досвід переживання такого стану сам по собі призводить до гармонізації і подальшого саморозвитку особистості. Зберігаючи даний стан у своїй пам’ яті (в тому числі, і в емоційній), людина може створювати цей стан у звичайному житті. Це, в свою чергу, впливає на ефективність процесу саморозвитку та самовдосконалення особистості [1].

Сучасний танець, як і сучасне мистецтво залишається багатогранним напрямком, що швидко розвивається, його можливості збільшуються 3 кожним днем, що робить цей напрямок танцю унікальним для вивчення в аспекті самовдосконалення особистості. Саме за допомогою відповідних рухів, міміки, жестів, поз та музики людина здатна передати свій настрій, почуття, переживання, влучно розкрити цілісний музично-руховий образ. Все це допомагає розвивати танцювальну творчість, під якою слід розуміти здібність людини до створення нових рухів, варіантів комбінування та ускладнення знайомих елементів, а також вміння самостійно імпровізувати в процесі музично-рухової діяльності, у відповідності до особливостей музичного твору на основі доступних танцювальних та образних рухів [3].

Для самовдосконалення особистості потрібно розвивати свої природні задатки, включаючи і розвиток творчих здібностей, через цілеспрямовану активність, творчу діяльність самої особистості, заснованих на науковому знанні певних законів, принципів і правил. Такий процес може активізуватися на заняттях з сучасної хореографії, зокрема в процесі танцювальної імпровізації. Тому в ході занять необхідно створювати умови для оптимального включення особистості в творчий процес, так як саме в творчій діяльності розвивається і1і творчий потенціал. Продуктивність мислення проявляється в схильності до творення і інтуїтивності пізнання і творчості.

Імпровізація стимулює особистість на глибоку внутрішню роботу, вимагає особистісного розвитку, індивідуальності, вимагає зміни мислення, особливого ставлення до свого тіла, до особистої історії, внутрішніх імпульсів, які стають, в якомусь сенсі, «співавторами» імпровізаційного танцю. К. Станіславський вважав, що імпровізація активізує несвідомі потенції художника, що вона позбавляє розум від інертності, що експромти «освіжають, дають життя і безпосередність нашій творчості. 
Розділ І. Ціннісні орієнтири духовно-інтелектуального виховання, розвиток духовно-інтелектуальних якостей особистості в умовах співпраці й інклюзії

Поняття «імпровізація» означає діяльність особистості, що створює «щось нове» і не пов'язане з віковими обмеженнями. В особистісному плані здатність до імпровізації не так заснована на наявних задатках, знаннях, уміннях, навичках, скільки розвиває їх, сприяючи становленню особистості, творенню самого себе як засіб саморозвитку та самовдосконалення [4].

Таким чином, значення танцю полягає у його спроможності забезпечувати гармонію фізичного і духовного, естетичного, художнього та творчого розвитку особистості; сприяти вдосконаленню іiї сутнісних сил, творчих якостей і здібностей, зростанню внутрішніх потенціалів, розвиткові пізнавальної активності й емоційної чутливості, естетичних потреб і смаків, стимулюванні прагнення до самовдосконалення.

\section{Список використаних джерел:}

1. Голдрич О. С. Методика викладання хореографії : навчальний посібник. Львів : «Сполом», 2006. 84 с.

2. Костенко М. А. Педагогічні умови професійно-творчого саморозвитку майбутнього вчителя : автореф. дис. ...канд. пед. наук : 13.00.04. Харків, 2004. $20 \mathrm{c}$.

3. Поклад I. М. Деякі аспекти виховання особистості засобами хореографічного мистецтва. Матеріали до українського мистецтвознавства (на пошану А. I. Мухи) : збірник наукових праць НАН України та Інституту мистецтвознавства, фольклористики та етнографії ім. М. Т. Рильського за матеріалами Міжнародної наукової конференції «Україна на межі тисячоліть: етнос, нація, культура». Київ, 2003. Вип. 3. С. 179-183.

4. Фриз П. І. Зміст, форма і сутність хореографічної культури та іï вплив на творчий розвиток особистості дитини. Музикознавчі студії. Наукові збірки ЛДМА імені М. В. Лисенка. Львів, 2007. Вип. 16. С. 15-23.

5. Шариков Д. І. Теорія, історія та практика сучасної хореографії : монографія. Київ : КиМУ, 2010. С. 26. 